\title{
Elemen Budaya Sebagai Daya Tarik Wisata Di Desa Wisata Pengotan, Kecamatan Bangli, Kabupaten Bangli, Provinsi Bali
}

INengah Edi Santika a,1, Ida Ayu Suryasih a,2

1edisantika612@yahoo.com,2idaayusuryasih@unud.ac.id

a Program Studi S1 Destinasi Pariwisata, Fakultas Pariwisata,Universitas Udayana, Jl. Dr. R. Goris, Denpasar, Bali 80232 Indonesia

\begin{abstract}
Pengotan Tourism Village has unique culture that being a typical of the village itself. But, Pengotan Tourism Village isn't known widely yet. The development which is not optimum and many obstacles make it happen. Based on that problems, this research aims to identify the cultural potentials, of Pengotan Tourism Village as a culture based tourism village in Bangli Subdistrict, Bangli Regency.

The method that used in this research especially on analyzing the data is qualitative descriptive analysis to determine the potentials and the obstacles of development. The datas are collected through observation, interviews, literature study, and documentation. The informants are determined using purposive sampling technique.

The result of this research is Pengotan Tourism Village has many potentials that can make it as a tourist attraction in Bangli Regency. The potentials are cultural such as handicrafts, tradition, history of Pengotan, architecture, arts and musics, community livelihood, religion, and language.
\end{abstract}

Keywords : potential culture, Pengotan Tourism Village, Tourist Attraction

\section{PENDAHULUAN}

Indonesia memiliki karakteristik kebudayaan dari masyarakat yang berupa kesenian, adat istiadat, mata pencaharian maupun kehidupan sehari-hari yang memiliki potensi kewisataaan (Maharini dan Arida, 2014). Badan Pusat Statistik (BPS) menyatakan bahwa Bali memiliki sekitar 1,5\% atau sekitar 3.094.000 jiwa dari 1.340 suku bangsa yang terdapat di Indonesia pada tahun Tahun 2016. Keberadaan suatu suku bangsa tentu memiliki kebudayaan yang diwariskan kepada generasi mudanya. Seperti halnya suku Bali yang mewariskan kesenian adat dan budayanya. Kepariwisataan Bali tidak lepas dari kebudayaan di Bali yang dijadikan atraksi bagi wisatawan.

Kabupaten Bangli adalah salah satu kabupaten di Bali yang memiliki sejumlah daya tarik wisata yang telah dikenal oleh wisatawan. Banyak dari daya tarik wisata tersebut berbasis budaya sebagai atraksi utama seperti Desa Penglipuran yang memiliki arsitektur tradisional dan hutan-bambunya, Pura Kehen yang memiliki arsitektur bangunan tradisional dan salah satu pura tua di Kabupaten Bangli, Desa Terunyan dengan tatanan pemakaman jenazah tidak sama dari tempat lainnya jenazah diletakkan dibawah Pohon Taru, dan Desa Bayung Gede yang memiliki lokasi pemakaman ari-ari sebagai atraksi wisata budaya di Bangli. Keanekaragaman budaya yang dimiliki oleh Kabupaten Bangli menjadikan daya tarik wisata budaya tersebut menarik untuk dikunjungi wisatawan.

Desa Wisata Pengotan adalah desa wisata di Bangli dan telah mengantongi SuratKeterangan DesaWisata serta menjadi bagian dari KSPN Ubud. Sehingga kesempatan untuk dapat berkembang menjadi terbukalebar. Selain harus mempersiapkan segala bagian kepariwisataan seperti atraksi, akses, fasilitas dan amenitas serta harus mempunyai aktor intelektual sebagai motor untuk mengarahkan rancangan sesuai dengan karakteristik desanya. Aktori ntelektual diharapkan mampu mengarahkan keadaan kepariwisataan yang mengakibatkan reaksi berantai seperti penguatan budaya dan lokal.

Namun kurangnya perhatian yang diberikan oleh stakeholder di Kabupaten Bangli dalam memanfaatkan potensi kebudayaan di Desa Pengotan membuat perkembangannya tersebut menjadi terhambat.

Berdasarkan hal tersebut diperlukan penelitian terkait potensi wisata budaya yang dimiliki Desa Wisata Pengotan. Hal tersebut menjadi penting untuk diangkat karena pengenalan potensi yang dimiliki suatu daya tarik wisata dapat meningkatkan minat dari stakeholder maupun wisatawan untuk mengembangkan dan berkunjung ke daya tarik wisata tersebut. 


\section{TINJAUAN PUSTAKA}

Penelitian ini menggunakan beberapa pedoman konsep dan teori untuk menganalisis data yang didapat di lapangan, yaitu:

1. Konsep potensi wisata : menerangkan bahwa potensi wisata adalah berbagai sumber daya yang terdapat di sebuah daerah tertentu yang bisa dikembangkan menjadi atraksi wisata (Pendit, 1999).

2. Konsep desa wisata : merupakan suatu bentuk integrasi antara atraksi, akomodasi dan fasilitas pendukung yang disajikan dalam suatu struktur kehidupan masyarakat yang menyatu dengan tata cara dan tradisi yang berlaku, desa wisata biasanya memiliki kecenderungan kawasan pedesaan yang memiliki kekhasan dan daya tarik sebagai tujuan wisata (Wiedu, 1993).

3. Konsep pariwisata budaya : merupakan jenis kepariwisataan yang menggunakan potensi budaya sebagai daya tarik wisata dominan sekaligus memberikan identitas bagi pengembangan pariwisata tersebut (Geriya, 1995). Shaw dan William, (1997) mendefinisikan bahwa kegiatan pariwisata memiliki 10 elemen budaya yang menjadi daya tarik wisata yaitu; kerajinan, tradisi, sejarah dari suatu tempat, arsitektur, makanan tradisional, seni tari dan musik, cara hidup masyarakat setempat, agama, bahasa, dan pakaian adat tradisional.

\section{METODE}

Penelitian ini dilakukan di Desa Pengotan, Kecamatan Bangli, Kabupaten Bangli, Provinsi Bali. Adapun ruang lingkup penelitian yang digunakan yaitu mengidentifikasi potensi wisata budaya yang dimiliki oleh Desa Wisata Pengotan terkait dengan 10 elemen budaya yang diantaranya adalah kerajinan, tradisi, sejarah dari suatu tempat/daerah, arsitektur, makanan

tradisionalnya, seni dan musik, carahidup masyarakat, agama, bahasa, pakaian tradisional yang memiliki peluang untuk dikembangkan sebagai daya tarik wisata.
Jenis dan sumber data dalam penelitian ini menggunakan jenis data kualitatif, seperti: hasil wawancara dengan aparatur desa dan juga masyarakat lokal untuk mengetahui 10 elemen budaya yang ditulis dengan deskriptif, sejarah dan gambaran umum lokasi penelitian, jenis data kuantitatif seperti jumlah penduduk Desa Pengotan, pekerjaan masyarakat lokal jumlah kunjungan wisatawan dan dua sumber data yaitu sumber data primer serta sumber data sekunder (Moleong, 2012). Dalam pengumpulan data menggunakan empat teknik, yaitu: observasi wawancara, studi kepustakaan, dan dokumentasi. Untuk menentukan informan menggunakan teknik purposive sampling, yaitu peneliti menetapkan lebih awal siapa saja yang menjadi sampelnya, dan menyebutkan statusnya masing-masing sesuai dengan keinginan dan tujuan peneliti (Mukhtar, 2013).

Teknik analisis data dalam penlitian ini menggunakan teknik analisis data deskriptif kualitatif yaitu dilakukan dengan langkah bekerja dengan data, mengorganisasikan data, mencari dan menemukan pola, menemukan apa yang penting dan apa yang dipelajari, serta memutuskan apa yang dapat diceritakan kepada orang lain berdasarkan data yang didapatkan (Moleong, 2012).

\section{HASIL DAN PEMBAHASAN}

Desa Wisata Pengotan berjarak sejauh $57 \mathrm{~km}$ dari Kota Denpasar dengan waktu tempuh sekitar dua jam. Desa wisata ini lokasinya berada sekitar tujuh kilometer ke selatan dari arah Penelokan yang menjadi daya tarik utama wisatawan di Bangli.

Sejarah Desa Wisata Pengotan berawal dari diserangnya Desa Pemuteran Karangasem oleh Kerajaan Panji Sakti. Sebagian masyarakat Desa Pemuteran menyelamatkan diri ke daerah Kerajaan Bangli. Setelah lama menetap di Kerajaan Bangli, warga Desa Pemuteran akhirnya diberikan lahan untuk dijadikan tempat tinggal di utara Kerajaan Bangli. Sampailah warga Desa Pemuteran di hutan yang banyak ditumbuhi pohon lateng dan juga banyak hewan pemakan kayu. akhirnya di berilah nama Pengotan oleh Raja Bangli saat itu.

Desa Wisata Pengotan belum memiliki lembaga atau organisasi yang mengatur kegiatan pariwisata di Desa Wisata Pengotan seperti Kelompok Sadar Wisata (Pokdarwis). Kegiatan pemeliharaan lingkungan dilakukan secara bergiliran oleh sekaa teruna-teruni (para 
pemuda dan pemudi) setiap banjarnya. Jumlah penduduk yang terdapat di Desa Wisata Pengotan berjumlah 3.824 orang yang terdiri dari 1.952 orang pria dan 1.872 orang wanita serta terdiri dari 1.011 kepala keluarga (KK).

Pertanian menjadi mata pencaharian utama di Desa Wisata Pengotan tercatat sebanyak 1.830 jiwa bergantung pada sektor pertanian. Mata pencaharian lainnya adalah peternakan 1.073 jiwa, swasta 38 jiwa, pegawainegeri 11 jiwa, wiraswasta 87 jiwa, sopir kendaraan umum 22 jiwa, dan 704 jiwa IRT.

Sementara dalam sektor pariwisata masyarakat belum memiliki kelompok sadar wisata, sehingga aktor intelektual atau elit dari masyarakat lokal sendiri dalam hal pariwisata belum terakomodir perannya dengan baik. Sebagai desa wisata, selain harus memiliki organisasi yang mendukung kegiatan kepariwisataan biasanya memiliki akomodasi yang dapat menunjang kegiatan kepariwisataan yang berlangsung seperti penginapan. Selain dari Bali Woso yang merupakan usaha pariwisata swasta yang salah satunya menawarkan perkemahan, tidak ada lagi usaha pariwisata lainnya yang menawarkan akomodasi untuk wisatawan yang ingin menginap. Jika pariwisata di Desa Pengotan ingin maju dan berkembang maka harus memanfaatkan potensi yang dapat dijadikan identitas pariwisata di Desa Pengotan sendiri. Sebagai contohnya adalah pariwisata budaya. Potensi budaya yang dimiliki Desa Pengotan dan dapat dijadikan sebagai hal yang menarik untuk diperlihatkan maupun dijadikan atraksi wisata diantaranya adalah :

\section{Kerajinan}

Kerajinan adalah kebudayaan lokal berwujud barang yang diciptakan dengan tujuan sarana suatu kebudayaan maupun mempermudah pekerjaan. Rumah industri yang dimiliki masyarakat desa pengotan mampu menciptakan ragam kerajinan. Kerajinn tersebut diantaranya :

\subsection{Dulang dan Bokor kayu}

Dulang dan Bokor adalah sarana untuk mempermudah kegiatan upacara umat Hindu, kerajinan ini dibuat dari kayu. Dulang dan bokor umumnya dipakai sebagai wadahpersembahan setiap kali persembahan Hindu. Pengerjaan dulang serta bokor lumayan rumit serta memakan waktu yang panjang.

Dulang dan bokor biasanya dibuat dari kayu jati, pohon nangka, ataupun pohon cempaka. Memahat ukirannya merupakan hal yang paling sulit. Namun kedetailan dan kerumitan pahatan menunjukan nilai yang semakin tinggi.

Tahapan pembuatan dulang dan bokor dapat menarik wisatawan. Wisatawan dapat melihat cara pembuatan dulang secara langsung yang dibuat oleh masyarakat lokal di Desa Wisata Pengotan.

\subsection{Keranjang}

Keranjang adalah hasilanyaman dan umumnya dijadikan penampung barang keprluan sehari-hari. Keranjag umumnya dipergunakan sebagai penampung makanan hewan, hasilpanen serta wadah sampah oleh masyarakat Desa Wisata Pengotan. Desa Wisata Pengotan mengawali kerajinan keranjang oleh kesadaran masyarakat untuk memanfaatkan bambu yang tersedia.

Proses menganyam keranjang juga dapat menarik wisatawan. Keranjang yang dibuat di rumah tradisional yang berada di pusat Desa Wisata Peengotan. Yang mempermudah wisatawan untuk menjumpai para pengrajin keranjang tersebut.

\section{Tradisi}

Tradisi adalah kebudayaan yang berakar dari kebiasaan kehidupan masyarakat terdahulu. Tradisi masyarakat Desa Wisata Pengotan tersebut diantaranya;

\subsection{Pernikahan}

Pernikahan atau

Meserah merupakan bagian tahapan terakhir serangkaian tradisi perkawinan. Fungsinya adalah pembersihan dari kemalaan (ketidak bersihan) dari pengantin tersebut sehingga diperkenankan melangsungkan tradisi hingga selesai. Diadakannya pernikahan secara massal bertujuan untuk meringankan biaya pernikahan bagi para pasangan pengantin. Pernikahan massal dilakukan dua kali dalam setahun yaitu pada saat sasih kapat (September-oktober) serta pada sasih Kedasa (februari-maret). Keunikan dari 
pernikahan massal tersebut adalah pada proses meserah yang dilakukan di Pura Desa adat pengotan.

pernikahan atau meserah dapat menjadi daya tarik bagi wisatawan. Kegiatan yang sudah dijadwalkan dua kali dalam satu tahun tersebut memiliki keunikan tersendiri. Tradisi yang dilakukan dalam meserah seperti pelemparan kendi tanah liat, dan proses masuknya kepala keluarga ke dalam sistem lulu apad atau sistem senioritas dalam sistem kepemimpinan adat.

\subsection{Kremasi/ Ngaben}

Ngaben adalah prosesi pembakaran jenazah dalam Agama Hindu yang diyakini sebagai kembalinya tubuh tersebut kepada panca maha bhuta di alam dan mengiringi jiwa tersebut untuk menuju ke alam berikutnya. Prosesi ngaben pada Desa Wisata Pengotan mngambiltanah dari atas lokasi penguburan keluargnya. Prosesi pengaben begitu singkat dan sederhana.

Ngaben masal diadakan antara dua hingga tiga taun skali serta pelaksanaannya saat sasih kaulu hingga sasih kasanga atau pada perkiraan Februari hingga pada Bulan Maret. Tradisi ngaben secara masal ini dilakukan ketika terdapat banyak orang yang akan diabenkan di Desa Wisata Pengotan sehingga jadwal ngaben masal tidak dapat dipastikan.

Ngaben masaldapat menjadi daya tarik tersendiri bagi wisatawan. Ngaben Masal dilakukan secara tradisional dan sesuai aturan atau dresta yang dipercayai oleh masyarakat setempat. Proses membawa tetampihan atau simbul dari mayat oleh keluara dilakukan secara bersama-sama menjadi daya tarik tersendiri dalam proses pengabenan. Proses menek medesa atau ahli waris yang mewakili sebagai lulu apad Desa Adat pengotan juga terkesan unik karena ahli waris hanya menggunakan kain Kamen dan Selendang sehingga terkesan tradisional dan kuno.

\subsection{BarisBabuan}

Baris Babuang merupakan tarian yang dipragakan oleh empat orang wakil dari Peduluan Desa, empat orang wakil dari KrameBanjar, dan keseluruhan anggota pemuda di desa. Sarana yang digunakan dalam tarian ini adalah pelepah dari pohon pisang.

Tradisi perang pelapah ditarikan setelah matahari terbenam, tradisi perang papah dapat menarik wisatawan karena tradisi perang papah hanya terdapat di Desa Wisata Pengotan. perang papah dilakukan secara bersamaan dan bebas memukul peserta di sekitarnya dengan ketentuan tidak boleh memukul di daerah kepala dan juga alat fitalnya.

\subsection{Ngusaba tegen}

Ngusaba tegen merupakn serangkaian tradisi yang diikuti oleh semua banjar di Desa Wisata Pengotan serta lokasinya berpusat pada areal Pura Desa. Tradisi syukuran atas setahun musim panen yang baik. Tradisi dalam upacara ini mempersembahkan buah dan penganan yang dibentuk menjadi bulat dengan bagian tengah mengoval. Masing-masing keluarga membuat sepasang persembahan, kemudian ditegen dan digantung di lokasi upacara. Dalam tradisi ngusaba tegen juga terdapat tradisi megibung atau makan bersama.

Serangkaian upacara ini dapat dijadikan sebagai salah satu potensi atraksi budaya di Desa Wisata Pengotan. Ngusaba tegen akan sangat memperkaya ragam aktifitas wisata yang disajikan seperti saat pembuatan tegenan.

\section{Arsitektur}

Desa Wisata Pengotan memiliki landscape dengan arsitektur desa tradisional. Arsitektur tersebut adalah rumah adat yang memiliki pakem tradisional kosala kosali sebagai acuan tata letak pembangunan rumah. Pakem tersebut membuat kondisi rumah yang satu dengan yang lain dari segi tinggi, jenis dan bentk bangunan hampir mirip dengan yang 
lainnya. pakem juga mengatur mengenai keberadaan bangunan seperti bale daja yang berfungsi sebagi tempat menyembah leluhur dan tempat tamu singgah, bale delod dengan fungsi sebagai tempat keluarga beristirahat, bale dauh sebagai tempat membuat sarana upacara keagamaan. Selain arsitekturnya Desa Pengotan memiliki jalan yang menghubungkan antara rumah-rumah warga dan pura. Landskap dengan menampilkan kesan desa di Bali yang tradisional tersebut cukup unik dan berpotensi sebagai daya tarik Desa Wisata Pengotan

Arsitektur landskap desa tradisional tersebut dapat menarik wisatawan, dimana landscape tersebut menyerupai Desa Wisata Penglipuran dengan tatanan desa memanjang dan memiliki angkul-angkul sebagai pintu masuknya dan rumah yang berderet memanjang menambah kesan tradisional dari Desa Wisata Pengotan. Rumah tersebut juga dapat digunakan sebagai homestay bagi wisatawan yang berkunjung.

\section{Seni tari dan musik}

Kebudayaan yang juga berkaitan erat dengan kegiatan masyarakat di Bali adalah seni tari dan juga musik. Pertunjukan kesenian tersebut sarat akan nilai kebudayaan yang diberikan jiwa. Desa Wisata Pengotoan mempunyai seni tari serta musik yang sering diselenggarakan pada kegiatan keagamaan maupun menghibur saat event tertentu. Kesenian tersebut diantaranya adalah :

\subsection{Wayang Wong}

Wayang wong adalah seni tari yang dipentaskan oleh sejumlah penari dengan menggunakan atribut topeng. Kesenian tersebut menceritakan etos Ramayana. Pementasan umumnya diselenggarakan dengan menyingkat serta mencari inti dari etos Ramayan tersebut.

Wayang wong adalah kebudayaan lampau keberadaannya tidak sering dapat dilihat pada daerah lainnya. Wayang wong mempunyai kekhasan sendiri pada pagelarannya.

Pagelaran Wayang Wong yang sudah mulai langka ini dapat dijadikan atraksi wisata dalam kegiatan pariwisata atau dapat dijadwalkan pementasannya agar menjadi hiburan tetap di Desa Wisata Pengotan.

\subsection{Tari-Baris}

Tari baris umumnya adalah seni tari yang pagelarannya saat kegiatan upacara menyembah Tuhan dalam masyarakat Hindu. Taribaris umumnya mengisahkan perang para pasukanprajurit. Senjata perang tersebut adalah tombak, perisai dan keris. Desa Wisata Pengotan memiliki delapan jenis tari baris yang masih dipertahankan. Desa Wisata Pengotan memiliki delapan jenis tari baris, namun yang paling disakralkan dan populer adalah BarisDadap, dan Baris Blongsong dan hanya satu-satunya di bali yaitu:

a. Baris dadab : adalah baris tersulit dari delapan tari baris yang terdapat di Desa Wisata Pengotan. Penari wajib diiringi dengan tembang pada pementasannya. Baris Dadab memiliki gerakan yang halus dan mengalun mengikuti irama tembang. Penari berjumlah delapan orang yang berasal dari keturunan keluarga yang mahir dalam menarikan baris ini. Baris dadab berpakaian lengkap seperti penari topeng pada umumnya, senjata yang dibawa adalah benda menyerupai perahu yang menyimbulkan keseimbangan dan rua binedha. Pementasan tari baris dadab hanya dapat dilihat pada saat upacara agama tertentu di Desa Wisata Pengotan.

b. Baris Blongsong : adalah baris dengan tombak paling panjang dari kedelapan tari baris yang ada. Tombak tersebut panjangnya sekitar lima meter. Baris blongsong mengisahkan perwira yang berwibawa. Tari Baris ini menggambarkan kedewasaan serta kemampuan perang yang baik. Baris Blongsong ditarikan oleh 12 orang dan diperankan oleh penari yang memiliki keahlian serta melalui latihan yang panjang. Baris 
blongsong adalah satu-satunya tari baris yang terdapat di Bali dan berada di Desa Wisata Pengotan. Pementasan tari baris yang terdapat di Desa Wisata Pengotan dilakukan pada saat hari tertentu yaitu pada saat piodalan di Pura Tuluk Biyu dan tidak dipentaskan salah satunya tetapi keseluruhan dari ke delapan soroh baris yang ada.

\subsection{Calonarang}

Calonarang adalah cerita rakyat Bali yang hingga kini masih dipentaskan dalam pertunjukan seni. Calonarang memiliki berbagai kisah, kisah yang paling populer adalah Katundung Ratna Manggali . Calonarang ini mengisahkan Ratna Manggali yang dicerai karena sang wanita mempunyai seorang ibu dengan kemampuan black magic bernama bhairawa pengiwa yang menyembah Dewi Durga. Hal tersebut membuat marah dari Calonarang hingga membuat kerajaan Kediri mengalami musibah. Untuk menghentikan musibah tersebut seorang pemuka agama bernama Mpu Bharadah akhirnya bertarung dengan Calonarang tersebut.

Pementasan Calonarang dapat menarik kunjunagan wisatawan. dalam pementasan calonarang hanya dilakukan pada upacara tertentu saja. Dan keunikan dari pementasan calonarang adalah wisatawan dapat menyaksikan pementasan barong yang memiliki mata tiga yang hanya satusatunya terdapat di Bali yaitu di Desa Wisata pengotan.

\subsection{Gandrung}

Gandrung adalah pertunjukan kesenian yang pagelarannya sulit ditemukan. Gandrung adalah seni tari yang hampir mirip dengan joged dan berfungsi sebagai penghibur. Selain berfungsi sebagai hiburan, ada juga Gandrung yang sifatnya sakral serta pementasannya dilakukan pada upacara agama. Untuk dapat melihat Gandrung ini dipentaskan maka wisatawan dapat mengunjungi Bali Woso Camp pada acara LobongPicnic di Desa Wisata Pengotan.

Gandrung merupakan tari hiburan bagi masyarakat. Pementasan tari gandrung masih sering dilakukan meskipun tari gandrung sudah jarang ditemui. Di Desa Wisata Pengotan terdapat penari gandrung lanjut usia yang lebih menambah kesan tradisional dari tari gandrung. Tari gandrung juga dapat dipentaskan serta sebagai hiburan tetap dan terjadwal di Desa Wisata Pengotan.

\subsection{Gamelan Kokan}

Gambelan kokan adalah alat musik tradisional yang unik dan langka yang dimiliki oleh Desa Wisata Pengotan. Gambelan kokan memiliki komposisi yang sama dengan bleganjur umumnya. Gambelan kokan memiliki ukuran yang beragam dan menimbulkan suara yang bervariasi. Ukuran kokan tersebut antara $50 \mathrm{~cm}$ hingga $150 \mathrm{~cm}$. Pagelaran gambelan tersebut umumnya dapat dilihat pada penyambutan tamupenting dan pada pagelaran Pesta KesenianBali.

Gambelan kokan dapat dijadikan atraksi wisata dan juga sebagai penyambutan wisatawan yang dapat masuk ke dalam paket tour. Selain itu gambelan kokan juga dapat dijadikan atraksi tetap melihat gambelan kokan hanya ada sedikit di Bali.

\subsection{Gong Gede}

Gong gede termasuk kedalam gambelan madya fungsinya adalah sebagai pengiring kegiatan pemujaan Tuhan serta tarian seperti tari baris, calnarang, dan sebagainya. Kelengkapan gambelan tersebut meliputi seluruh instrumen gong perunggu Bali. Gong gede tersebut dipentaskan saat kegiatan dewa yadya pada pura terbesar di Desa Wisata Pengotan.

\section{Cara hidup masyarakat}

Kebudayaan masyarakat Desa Wisata Pengotan untuk cara hidupnya tidak berbeda dari masyarakat perdesaan lainnya. Masyarakat tersebut mayoritas adalah petani. Sistem pertaniannya masih tradisional karena masih 
memiliki keterbatasan pengetahuan tentang mekanisme pertanian. Hasil pertanian tersebut digunakan sebagai pendapatan ekonomi dan pemenuhan kebutuhan masyarakat .

Masyarakat yang menggeluti bidang pertanian lahan kering dapat menjadi daya tarik pendukung dalam kegiatan pariwisata . kegiatan pertanian menjadi atraksi wisata dimana wisatawan dapat langsung ikut serta dalam kegiatan pertanian yang masih tergolong pertanian tradisional.

\section{Agama}

Masyarakat di Desa Wisata Pengotan mayoritas beragama Hindu dan memiliki tempat suci berupa pura. Desa tersebut tergolong pada Desa Bali Aga. Desa Bali Aga merupakan masyarakat tertua asli Pulau Bali. Bali Ags diartikan sebagai orangBali yang berasal dari daerah gunung. Leluhur penduduk Desa Wisata Pengotan berawal dari daerah DesaPemuteran Kabupaten Karangasem dan sejak dahulu dikenal sebagai Desa Bali Aga.

Desa Wisata Pengotan menganut agama hindu yang tidak terlepas dari kegiatan adatistiadat, upacara agama dan tradisi yang dimiliki Desa Wisata Pengotan. Seluruh kegiatan agama yang dilakukan di Desa Wisata Pengotan berpotensi menjadi atraksi budaya bagi wisatawan. Desa Bali Aga juga menambah kesan tradisional yang memiliki kebudayaan yang kental dan masih dipertahankan.

\section{Bahasa}

Bahasa adalah serangkaian metode berinteraksi yang dipakai oleh manusia dalam menyampaikan pesan seperti dengan simbol visual maupun suara. Bahasa di masing-masing tempat di Bali mempunyai logat unik pada setiap daerahnya. Perbedaan dialek tersebut menjadikan kekhasan tersendiri bagi setiap daerah asalnya. Bahasa Bali memiliki tingkatan bahasa yang dikenal sebagai sor singgih bahasa. Adapun bahasa tersebut terdiri dari baasa kasar, baasa madya, dan baasa alus. Baasa alus dipergunakan pada acara resmi sepertihalnya rapat adat, peminangan mempelai perempuan, dan antara penduduk yang kastanya lebih rendah terhadap penduduk berkasta lebih tinggi semisal antara masyarakat biasa dengan keturunan raja. Baasa madya dipergunakan oleh penduduk kelas menengah sebagai contoh antara pjabat dan bawahannya, dan antara penduduk setempat dengan golongan warnasudra. Baasa kasar dipergunakan oleh bangsawan terhadap kaum sudra, maupun antara kaum sudra sendiri.

Kosa kata yang dimiliki penduduk cukup singkat. Kosa kata tersebut lebih sering memakai "a" sebagai pengganti huruf "e" pada akhiran setiap kata di Bali. Sebagai contoh kata "lakar kije?" adalah kata pada bahasa bali umumnya yang memiliki arti "mau kemana?" diucapkan "kal kije" di Desa Wisata Pengotan. Dialek ini menjadi ciri khas yang kental dan sulit dihilankan dari masyarakat Desa Wisata Pengotan meskipun tengah merantau.

Kedelapan elemen kebudayaan tersebut merupakan kekhasan yang dipunyai Desa Wisata Pengotan .Namun diantara delapan elemen tersebut arsitektur, tradisi, dan seni tari dan musik menjadi yang paling unik dan potensial untuk dijadikan sebagai atraksi wisata berbasis budaya di Desa Pengotan.

\section{SIMPULAN DAN SARAN}

\section{A. Simpulan}

Potensi budaya sebagai daya tarik wisata yang dimiliki oleh Desa Wisata Pengotan mempunyai delapan elemen kebudayaan. Kedelapan elemen kebudayaan tersebut merupakan kekhasan yang dipunyai Desa Wisata Pengotan. Namun diantara delapan elemen tersebut arsitektur, tradisi, dan seni tari dan musik menjadi yang paling unik dan potensial untuk dijadikan sebagai atraksi wisata berbasis budaya di Desa Pengotan.

\section{B. Saran}

Saran yang diberikan sebagai masukan untuk pengembangan potensi budaya di Desa Wisata Pengotan adalah Pemerintah melihat kendala yang terjadi di Desa Wisata Pengotan dan membantu di dalam pengembangannya. Pemerintah Kabupaten Bangli diharapkan melakukan promosi baik melalui sarana fisik maupun elektronik seperti website dan juga memberikan pelatihan kepada masyarakat lokal agar meningkatkan kualitas dan kreatifitas sumber daya manusianya. Untuk pemerintah desa sebaiknya membentuk Pokdarwis yang tugasnya optimalisasi manajemen Desa Wisata Pengotan

Penduduk setempat diharapkan mampu mengelola lingkungan pada rumah tradisionalnya, dan teruntuk investor swasta diharapkan membantu Desa Wisata Pengotan 
Vol. 6 No 1, 2018

untuk dapat mengoptimalkan kunjungan

wisatawan.

Peneliti berikutnya diharapkan mampu menggali isu-isu strategis kepariwisataan di Desa Wisata Pengotan untuk sumbangan akademis dalam memanajamen desa wisata tersebut.

\section{DAFTAR PUSTAKA}

Geriya, Wayan. 1995. Pariwisata dan Dinamika Kebudayaan Lokal, Nasional, Global. Denpasar : Upada Sastra

Koentjaraningrat. 2011. Pengantar Antropologi I. Jakarta: Rineka Cipta.

Maharini, D.A Eka dan Sukma Arida. 2014. Keterlibatan Masyarakat Dalam Mengelola Desa Wisata Pangsan Di Kabupaten Badung. Jurnal Destinasi Pariwisata, Vol. 2 No. 1.

Mukhtar. 2013. Metode Penelitian Deskriftif Kualitatif. Jakarta : GP Press Group.

Moleong, Lexy J. 2012. Metodologi Penelitian Kualitatif. Bandung : PT. Remaja Rosdakarya

Pendit, Nyoman S. 1999. Ilmu Pariwisata. PT. Pradya Pratama. Jakarta

Putra, Darma dan I Gde Pitana.2010. Pariwisata ProRakyat. Jakarta: Kementerian Kebudayaan dan Pariwisata.

Shaw, G, and William, A. M. 1997. Critical Issue in Tourism. Blackwell Publiser. Oxford

Suryawan, Ida Bagus., Suryasih Ida Ayu., dkk. 2016. Buku Perkembangan dan Pengembangan Desa Wisata. Bogor: Herya Media 